\title{
PENGARUH OUTDOOR EDUCATION BERLANDASKAN EXPERIENTIAL LEARNING TERHADAP KREATIVITAS
}

\author{
Asep Ramdan Afriyuandi
}

Pendidikan Jasmani Kesehatan dan Rekreasi

Fakultas Keguruan dan Ilmu Pendidikan, Universitas Suryakancana

sps.afriyuandi@gmail.com

\begin{tabular}{l}
\hline Info Artikel \\
\hline Sejarah Artikel: \\
Diterima Oktober 2018 \\
Disetujui November 2018 \\
Dipublikasikan Desember \\
2018
\end{tabular}

\begin{abstract}
Abstrak
Outdoor education berlandaskan experiential learning merupakan sarana menambah pengalaman belajar dan menjadi pelajaran yang sangat penting membawa perubahan bagi kehidupan seseorang. Pengalaman yang ditemukan tentunya sangat mendidik, artinya bahwa pengalaman tersebut memberikan pengertian yang sangat mendalam dan melampaui pengalaman yang hanya merupakan sebuah transaksi dari seseorang dan lingkungan yang dirasakan itu. Berdasarkan konsep-konsep diatas maka outdoor education dilakukan berlandaskan experiential learning, yang ditujukan untuk meningkatkan kreativitas.. Tujuan dalam penelitian ini adalah ingin mengetahui pengaruh dari Outdoor Education
\end{abstract} berlandaskan Experiential Learning terhadap kreativitas. Metode yang digunakan adalah Quasi Eksperimen dengan pendekatan Non-Randomized Control Group PretestPostest Design. Sampel dalam penelitian ini adalah pecinta alam mahasiswa olahraga (pamor) yang mengikuti kegiatan outdoor education sebanyak 20 orang, dan siswa bukan anggota pecinta alam yang tidak mengikuti outdoor education dalam jumlah yang sama. Sampel tersebut diambil dengan cara purposive sampling. Hasil penelitian menunjukan bahwa aktivitas outdoor education berlandaskan experiential learning memberikan pengaruh signifikan terhadap kreativitas dengan nilai $\mathrm{t}$ hitung $5,2>\mathrm{t}$ tabel 1,68 dengan taraf $\alpha 0,05 \mathrm{dan} \mathrm{dk}=\mathrm{n} 1+\mathrm{n} 2-2$. Kesimpulan dalam penelitian ini adalah aktivitas outdoor education berlandaskan experiential learning memberikan pengaruh signifikan terhadap kreativitas.

Keyword:

Outdoor

Kreativitas.

Outdoor education based on experiential learning is one of facilities to add learning experience and to be a lesson that is very important to bring a change in someone's life. The experiences found surely very educate means that the experience itself gives a deep understanding and experience beyond just a transaction of someone and the perceived environment. Based on 


the concepts above, the outdoor education is done based on
experiential learning, which is intended to increase the
creativity. A Quasi Experiment method with Non-Randomized
Control Group Pretest-Posttest Design approach was used in
this study. The sample of this study is the member of PAMOR who
is participated in outdoor education activity as many as 20
people, and the student which is not a member of PAMOR who
does not participated in outdoor education activity in the same
amount. The sample was taken by purposive sampling. The result
of this study shows that activity of outdoor education based on
experiential learning has a significant impact to creativity with a
t value of 5.2> t table $\alpha$ level of 1.68 to 0.05 and df $=n 1+n 2-$
2. The conclusion of this study is an outdoor activity education
based on experiential learning has significant impact on
creativity.

(C) 2018 Universitas Suryakancana

\begin{tabular}{l}
\hline Alamat korespondensi: \\
E-mail: \\
Adirahadian@unsur.ac.id
\end{tabular}
e-ISSN : 2721-7175 (online)

p-ISSN : 2089-2341 (cetak)

\section{PENDAHULUAN}

Pendidikan pada dasarnya adalah usaha sadar untuk menumbuh kembangkan potensi sumber daya manusia peserta didik dengan cara mendorong dan memfasilitasi kegiatan belajar mereka. Undang-Undang Republik Indonesia Nomor 20 Tahun 2003 tentang Sistem Pendidikan Nasional pun secara jelas mendefinisikan pendidikan sebagai usaha sadar dan terencana untuk mewujudkan suasana belajar dan proses pembelajaran agar peserta didik secara aktif mengembangkan potensi dirinya. Pengembangan potensi diri tersebut bertujuan untuk memiliki kekuatan spiritual keagamaan, pengendalian diri, kepribadian, kecerdasan, akhlak mulia serta keterampilan yang diperlukan dirinya, masyarakat, bangsa dan negara. Kreativitas merupakan suatu tuntutan pendidikan dan kehidupan yang sangat penting pada saat ini. Kreativitas akan menghasilkan berbagai inovasi dan perkembangan baru dalam suatu kehidupan. Individu dan organisasi yang kreatif akan selalu dibutuhkan oleh lingkungannya karena mereka dapat mampu memenuhi kebutuhan lingkungan yang terus berubah dan mampu untuk bertahan dalam kompetisi global yang dinamis dan ketat.

Kreativitas adalah kemampuan untuk menciptakan atau menemukan sesuatu ynag baru, dan atau memodifikasi sesuatu yang sudah ada sehingga manfaatnya 
47 | Asep Ramdan Afriyuandi

Pengaruh Outdoor Education Berlandaskan Experiential Learning Terhadap Kreativitas

bernilai lebih dibanding sebelumnya. Manusia kreatif sangat dibutuhkan dalam mengantisipasi dan merespon secara efektif ketidakmenentuan perubahan saat ini. Perkembangan kebudayaan dan peradaban juga terjadi berkat kreativitas orang-orang yang istimewa dalam berbagai sektor kehidupan seperti politik, ekonomi, militer, teknologi, pendidikan, agama, kesenian, olahraga, dan lain-lain. Kreativitas siswa dimungkinkan tumbuh dan berkembang dengan baik, apabila lingkungan keluarga, masyarakat, maupun lingkungan sekolah, turut menunjang mereka dalam mengekpresikan kreativitasnya.

Menurut Munandar (1999:45) "Kreativitas penting dipupuk dan dikembangkan dalam diri anak. Alasan pertama, karena dengan berkreasi orang dapat mewujudkan dirinya, dan perwujudan diri termasuk salah satu kebutuhan pokok dalam hidup manusia. Kedua, kreativitas atau berpikir kreatif sebagai kemampuan untuk melihat bermacam-macam kemungkinan penyelesaian terhadap suatu masalah. Pemikiran kreatif perlu dilatih, karena membuat anak lancar dan luwes (fleksibel) dalam berpikir, maupun melihat suatu masalah dari berbagai sudut pandang, dan mampu melahirkan banyak gagasan. Ketiga, bersibuk diri secara kreatif tidak hanya bermanfaat, tetapi juga memberikan kepuasan individu. Keempat, kreativitaslah yang memungkinkan manusia meningkatkan kualitas hidupnya”.
Kreativitas penting dimiliki oleh setiap orang. Suatu keterampilan yang dimiliki setiap orang jika dikembangkan dengan adanya kreativitas maka akan menciptakan hal yang baru dalam memberikan ide-ide, inovasi, hingga mengatasi masalah secara kreatif. Seperti yang diungkapkan Supriadi (1994:7) bahwa kreativitas adalah "kemampuan

seseorang untuk melahirkan sesuatu ya ng baru, baik berupa gagasan maupun karya nyata yang relatif berbeda dengan apa yang telah ada."

Tampak adanya fenomena bahwa dalam proses pembelajaran pendidikan jasmani di sekolah, masih ada kecenderungan terhadap pengekangankebebasan siswa, pembelajaran masih banyak didominasi guru, sehingga siswahanya berperan sebagai pelaksana terhadap perintah guru, siswa tidak mendapat kebebasan untuk mengekspresikan dirinya. Jika hal tersebut dibiarkan, dikhawatirkan akan berdampak negatif terhadap pengembangan kreativitas siswa. Padahal kreativitas penting untuk dipupuk dan dikembangkan, karena kreativitasmemang sangat dibutuhkan terutama berkaitan dengan pembangunan Indonesiayang membutuhkan sumber daya manusia berkualitas yang memiliki kreativitas tinggi.

Pendidikan jasmani memberikan kontribusi yang berarti terhadap pertumbuhan dan perkembangan peserta didik secara menyeluruh. Kontribusi akan bermakna, jika proses belajar mengajar pendidikan jasmani memberikan 
48 | Asep Ramdan Afriyuandi

Pengaruh Outdoor Education Berlandaskan Experiential Learning Terhadap Kreativitas

perubahan perilaku dan pengetahuan terhadap peserta didik. Pendidikan jasmani menurut Lutan (2000:16) adalah "bagian integral dari pendidikan keseluruhan yang memberi kontribusi kepada perkembangan individu melalui media alamiah yaitu aktifitas fisik dan gerak termasuk olahraga".Prioritas utama dalam upaya peningkatan pendidikan jasmani di sekolah, yaitu dengan perwujudan secara optimal peranan dan fungsi guru dalam kegiatan belajar mengajar baik diruangan maupun di lapangan.

Berdasarkan pokok pikiran tersebut dalam pelaksanaannya proses pendidikan dapat dilaksanakan dengan berbagai pendekatan dan kegiatan belajar pada beberapa kajian mata pelajaran. Namun di samping itu semua sebagai langkah pengembangan dalam dunia pendidikan, proses pembelajaran yang tujuannya untuk mengembangkan seluruh potensi pada diri individu, dewasa ini dilakukan dengan penerapan pembelajaran Outdoor Education dengan alam sebagai medianya. Aktivitas luar sekolah (Outdoor Education) berisi tentang kegiatan di luar kelas/sekolah dan di alam bebas lainnya, seperti; bermain di lingkungan sekolah, taman, perkampungan pertanian/nelayan, dan kegiatan yang bersifat kepetualangan, serta pengembangan aspek pengetahuan/konsep yang relevan serta nilai-nilai yang terkandung di dalamnya.Oleh karena itu, Outdoor Education dapat menjadi wahana dalam mengembangkan potensi diri siswa, tentunya dengan kegiatan yang melibatkan faktor dan aktifitas fisik yang dilaksanakan di lapangan atau diluar ruangan.

Proses pembelajaran menggunakan alam sebagai media dipandang sangat efektif dalam knowledge management dimana setiap orang akan dapat merasakan, melihat langsung bahkan dapat melakukannya sendiri, sehingga transfer pengetahuan berdasarkan pengalaman di alam dapat dirasakan, diterjemahkan, dikembangkan berdasarkan kemampuan yang dimiliki. Pendekatan ini mengasah aktivitas fisik dan social anak dimana anak akan lebih banyak melakukan kegiatankegiatan yang secara tidak langsung melibatkan kerjasama antar teman dan kemampuan berkreasi. Aktivitas ini akan memunculkan proses komunikasi, pemecahan masalah, kreativitas, pengambilan keputusan, saling memahami, dan menghargai perbedaan.

Kegiatan Outdoor Education sendiri lebih banyak melibatkan faktor dan aktifitas fisik yang dilaksanakan di lapangan atau diluar ruangan. Selanjutnya dikatakan oleh Miles and Priest $(1990 ; 1)$ : mengenai proses pengalaman dan proses pendidikan seseorang melalui kegiatan Outdoor Education ini yaitu "Adventure for the goals of growth and human development. Adventure education involves the purposeful planning and plementation of educational processes that involve risk in some way, the risk may be physycal, social and spiritual." 
49 | Asep Ramdan Afriyuandi

Pengaruh Outdoor Education Berlandaskan Experiential Learning Terhadap Kreativitas

Dalam Kardjono (2009:19) “experiential learning ini memberikan peluang kepada seseorang untuk memperoleh pengalaman, menghasilkan makna tersendiri bagi orang tersebut. Oleh karena itu pengalaman yang bermakna tersebut harus memasukan waktu yang dikhususkan untuk perenungan".Menurut Tanighuci dalam Kardjono (2009:20) “experiential learning melalui outdoor education menawarkan titik gairah untuk mengacu pada proses belajar dari sudut pandang si pelajar, bukan semata-mata dari sudut pandang sang guru".

Adapun identifikasi masalah penelitian ini sebagai berikut: 1) Proses pembelajaran pendidikan jasmani di sekolah, masih ada kecenderungan terhadap pengekangankebebasan siswa, pembelajaran masih banyak didominasi guru, siswahanya berperan sebagai pelaksana terhadap perintah gurusehingga akan berdampak negatif terhadap pengembangan kreativitas siswa. 2) Proses pembelajaran Outdoor Education dengan alam sebagai medianya, yang didalam kurikulum pendidikanya diharapkan mampu mengembangkan pembentukan karakter siswa tetapi belum diterapkan secara serius oleh para guru penjas sebagai salah satu media pembelajaran jasmani. 3) Kecenderungan kreativitas diajarkan hanya sebatas teori dan siswa tidak diberikan suatu pengalaman belajar untuk mengembangkan kreativitas.

Maksud dan tujuannya adalah dari proses pembelajaran atau pendidikan dan proses pengalaman ini merupakan suatu hal yang sangat berguna untuk perkembangan, pertumbuhan, dan kemajuan manusia. Sedangkan proses pendidikan melalui kegiatan ini sendiri memiliki maksud dan tujuan yang melibatkan perencanaan dalam pendidikan melalui berbagai macam proses yang melibatkan resiko dalam suatu perjalanan, yang banyak melibatkan resiko fisik, sosial dan spiritual. Melalui kegiatan Outdoor Education ini siswa diharapkan menjadi lebih kreatif dalam menciptakan ide-ide, inovasi, dan gagasan baru dalam menghadapi suatu permasalahan. Berdasarkan pada latar belakang di atas maka dalam hal ini, penulis tertarik untuk Permasalahan yang harus diungkap lebih lanjut dalam penelitian ini adalah sebagai berikut: 1) Apakah terdapat pengaruh yang signifikan dari Outdoor Education yang berlandaskan Experiential Learning terhadap kreativitas siswa? 2) Apakah terdapat ciri kreativitas pada siswa dilihat dari ciri kognitif (aptitude) dan ciri afektif (non-aptitude) sebelum dan sesudah penerapan Outdoor Education yang berlandaskan Experiential Learning.

\section{METODE PENELITIAN}


50 | Asep Ramdan Afriyuandi

Pengaruh Outdoor Education Berlandaskan Experiential Learning Terhadap Kreativitas

Variabel yang digunakan dalam penelitian ini adalah variabel bebas dan variabel terikat. Variabel bebas dalam penelitian ini yaitu, outdoor education dan variabel terikat dalam penelitian ini adalah kreativitas. Metode yang digunakan adalah quasi eksperimen dengan pendekatan Non-

Randomized Control Group Pretest-

\begin{tabular}{|l|l|l|l|l|l|}
\hline Putra & $\begin{array}{l}19- \\
21 \\
\text { th }\end{array}$ & $\begin{array}{l}12 \\
\text { org }\end{array}$ & Putra & $\begin{array}{l}19- \\
21 \\
\text { th }\end{array}$ & $\begin{array}{l}12 \\
\text { org }\end{array}$ \\
\hline & $\begin{array}{l}21 \\
21 \\
\text { th }\end{array}$ & org & & $\begin{array}{l}21 \\
\text { th }\end{array}$ & org \\
\hline
\end{tabular}

Postest Design.

\begin{tabular}{|c|c|c|c|}
\hline Eksperimen & $\begin{array}{l}\text { Pre } \\
\quad T_{1}\end{array}$ & $\underset{X}{\text { Treatment }}$ & $\begin{array}{r}\text { Post } \\
T_{2}\end{array}$ \\
\hline Kontrol & $\mathbf{T}_{1}{ }^{1}$ & $\sim$ & $\mathbf{T}_{2}{ }^{1}$ \\
\hline
\end{tabular}

Sampel dalam penelitian ini adalah siswa pecinta alam yang mengikuti kegiatan outdoor education sebanyak 40 orang, dan siswa bukan anggota pecinta alam yang tidak mengikuti outdoor education dalam jumlah yang sama. Besar sampel seluruhnya yang diambil yaitu 12 putra dan 8 putri yang bersedia untuk mengikuti penelitian secara terus-menerus hadir dalam kegiatan penelitian. Untuk lebih jelasnya dapat dilihat dalam tabel dibawah ini.

Tabel Pembagian Kelompok

Penelitian

\begin{tabular}{|c|c|c|c|c|c|}
\hline \multicolumn{3}{|c|}{ Kelompok } & \multicolumn{3}{c|}{ Kelompok Kontrol } \\
Eksperimen & \multicolumn{2}{l|}{} \\
\hline Jenis & Usia & Ju & Jenis & Usia & Ju \\
Kelam & & mla & Kela & & mla \\
in & & h & min & & h \\
\hline
\end{tabular}


dan kontrol dapat dilihat pada tabel

dibawah ini.

Tabel Uji normalitas data gain diuji menggunakan Liliefors
Berikut mengenai uji homogenitas gain kreativitas, pada kelompok eksperimen dan kontrol dapat dilihat pada tabel dibawah ini.

Tabel Uji Homogenitas Gain Score Kreativitas Total

\begin{tabular}{|c|c|c|c|c|c|c|}
\hline Postes & $\mathrm{L}_{0}$ & $\begin{array}{l}\mathrm{L} \\
\text { Tabel } \\
(\mathrm{dk}=20)\end{array}$ & Kesimpulan & \multicolumn{3}{|c|}{$\begin{array}{c}\text { Tabel Uji Homogenitas Gain } \\
\text { Score Kreativitas Total }\end{array}$} \\
\hline Eksperimen & 0,124 & 0,190 & $\begin{array}{l}\text { Berdistribu\$pata } \\
\text { Normal }\end{array}$ & $\begin{array}{l}\mathrm{F} \\
\text { hitung }\end{array}$ & $\begin{array}{l}\mathrm{F} \\
\operatorname{tabel}_{(\alpha}\end{array}$ & Kesimpulan \\
\hline Kontrol & 0,105 & 0,190 & $\begin{array}{l}\text { Berdistribusi } \\
\text { Normal }\end{array}$ & & $\begin{array}{l}=0,05 \\
\mathrm{dk} 1=19, \\
\mathrm{dk} 2=19)\end{array}$ & \\
\hline & Dari & perh & $\begin{array}{ll} & \text { Gain } \\
\text { tungan uji }\end{array}$ & 1,358 & 2,21 & Homogen \\
\hline
\end{tabular}

normalitas gain kelompok

eksperimen dan kelompok kontrol diperoleh nilai $\mathrm{L}_{0}$ atau selisih terbesar kelompok eksperimen sebesar 0,124, sedangkan pada kelompok kontrol sebesar 0,105. Pada $\mathrm{L}_{\text {tabel }}$ dengan taraf nyata $\alpha=$ 0,05 dengan jumlah responden $\mathrm{n}=$ $20 \mathrm{dk}(20)$ menunjukkan nilai 0,190. Dengan kriteria pengujian, tolak hipotesis nol $\left(\mathrm{H}_{0}\right)$ jika $\mathrm{L}_{0}$ lebih besar dari L tabel. Dari perhitungan di atas, harga $\mathrm{L}_{0}$ kelompok eksperimen dan kontrol lebih kecil dari L tabel yang berarti bahwa data gain kreativitas kelompok eksperimen dan kelompok kontrol berdistribusi normal.

\section{Uji Homogenitas Gain}

\section{Kreativitas}

Dari perhitungan uji homogenitas gain kelompok eksperimen dan kelompok kontrol diperoleh nilai $\mathrm{F}$ hitung adalah 1,358 dan pada $\mathrm{F}$ tabel dengan taraf nyata $\alpha=0,05$ dengan $\mathrm{dk}$ pembilang $=\mathrm{n}$ $1=20-1=19$ dan $\mathrm{dk}$ penyebut=n1=20-1-19 menunjukkan nilai 2,21. Dengan kriteria pengujian, jika $F_{\text {hitung lebih kecil atau sama }}$ dengan $\mathrm{F}_{\text {tabel }}$, maka hipotesis nol $\left(\mathrm{H}_{0}\right)$ diterima. Dari perhitungan di

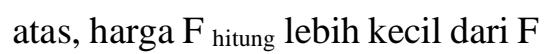
tabel yang berarti bahwa data gain antara kelompok eksperimen dan kelompok kontrol memiliki varians sama atau homogen.

Uji Perbedaan/Kesamaan Dua

\section{Rata-Rata Gain Kreativitas}

Berikut mengenai uji perbedaan/kesamaan dua rata-rata 
52 | Asep Ramdan Afriyuandi

Pengaruh Outdoor Education Berlandaskan Experiential Learning Terhadap Kreativitas

gain kreativitas, pada kelompok eksperimen dan kontrol dapat dilihat pada tabel dibawah ini.

Tabel Uji Perbedaan/kesamaan dua rata-rata gain Kreativitas

\begin{tabular}{|c|c|c|c|c|}
\hline Dat & $\begin{array}{c}\text { Rata- } \\
\text { Rata } \\
\text { Kelompo } \\
\mathrm{k} \\
\text { Eksperi } \\
\text { men }\end{array}$ & $\begin{array}{c}\text { Rata- } \\
\text { Relomp } \\
\text { ok } \\
\text { Kontrol }\end{array}$ & hitung & tabel \\
\hline $\begin{array}{c}\text { Gai } \\
\mathrm{n}\end{array}$ & 0,63 & 0,37 & $\begin{array}{c}5,25 \\
1\end{array}$ & $\begin{array}{c}1,68 \\
6\end{array}$ \\
\hline
\end{tabular}

Dari uji perbedaan atau kesamaan dua ratarata antara kelompok eksperimen dan kelompok kontrol dilihat dari variabel kreativitas pada gain, diperoleh nilai ratarata kelompok eksperimen yang berbeda dengan nilai rata-rata kelompok kontrol. Dari perhitungan diperoleh $\mathrm{t}_{\text {hitung }}=5,251$ dan $\mathrm{t}$ tabel pada taraf $\alpha=0,05$ dengan $\mathrm{dk}=\mathrm{n} 1+\mathrm{n} 2-2=20+20-2=38$ menunjukkan angka 1,686. Jika $\mathrm{t}$ hitung lebih besar dari $\mathrm{t}$ tabel, maka hipotesis nol $\left(\mathrm{H}_{0}\right)$ ditolak, hal ini menunjukkan bahwa rata-rata gain kelompok eksperimen dan kelompok kontrol berbeda atau rata-rata gain kelompok ekperimen lebih baik daripada kelompok kontrol.

\section{DISKUSI TEMUAN}

Diskusi temuan ini dilakukan berdasarkan hasil penelitian yang telah didapat dari lapangan beserta kajian teori yang telah dijelaskan pada bab sebelumnya. Pembahasan dalam penelitian ini bertujuan untuk menerangkan dan menginterprestasikan hasil penelitian dan tujuan penelitian. Setelah dilakukan analisis tehadap masing-masing variabel kemudian dilakukan perhitungan untuk melihat pengaruh dari outdoor education berlandaskan experiential learning terhadap kreativitas, kemudian dilakukan pembahasan pada hasil penelitian yang didapat

Dalam penelitian yang telah dilakukan tersebut, diperoleh hasil yang menyatakan bahwa ada suatu pengaruh yang signifikan antara mahasiswa yang melakukan kegiatan outdoor education berlandaskan experiential learning dengan yang tidak melakukan kegiatan tersebut. Hal ini dapat diartikan bahwa outdoor education berlandaskan experiential learning berpengaruh secara signifikan terhadap kreativitas mahasiswa. Sehingga hipotesis yang diajukan dapat diterima.

Outdoor education berlandaskan experiential learning dapat merangsang dan meningkatkan kreativitas siswa menjadi lebih baik daripada siswa yang tidak terlibat langsung dalam kegiatan tersebut. Pengalaman-pengalaman tersebut haruslah bersifat mendidik. Taniguchi dalam Kardjono (2009: hlm.130) “ the experience provides the student with the opportunity to have inherent interest in what happen in the experience and the student has a change for reflection". Artinya adalah pengalaman ini 
53 | Asep Ramdan Afriyuandi

Pengaruh Outdoor Education Berlandaskan Experiential Learning Terhadap Kreativitas

memberikan siswa peluang untuk membuat minat yang melekat pada apa yang terjadi dalam pengalaman itu dan memberi siswa kesempatan untuk memikirkan. Renungan ini harus memusatkan pengalaman ke dalam konteks yang sudah dipelajari sebelumnya. Terdapat perbedaan pengaruh terhadap peningkatan kreativitas mahasiswa pada aspek fluiditas (kelancaran), aspek fleksibilitas (keluwesan), aspek orisinalitas (keaslian), aspek elaborasi (kerincian), aspek evaluasi (penilaian), aspek rasa ingin tahu, aspek imajinatif, aspek tertantang oleh kemajemukan, aspek berani mengambil resiko dan aspek menghargai pada sampel penelitian menjadi lebih baik setelah mengikuti kegiatan outdoor education di alam terbuka yang berlandaskan experiantal learning melalui kegiatan hiking, rafting, rock climbing, dan camping. Hasil analisis untuk kelompok eksperimen adalah pada aspek fleksibilitas (keluwesan), sedangkan untuk kelompok kontrol terdapat pada aspek elaborasi (kerincian), hal tersebut menunjukkan adanya peran yang signifikan antara kelompok eksperimen dan kelompok kontrol.

Pendapat tersebut menegaskan bahwa penelitian yang telah dilakukan oleh peneliti memiliki pengaruh yang signifikan bagi kreativitas yang mana kreativitas termasuk dalam kemampuan kognitif dan afektif, sehingga kemampuan kognitif dan afektif akan terlatih apabila anak diberikan suatu kegiatan outdoor education berlandaskan experiential learning. Sejalan dengan Rhodes (dalam Munandar, 2009, hlm.20) mengemukakan bahwa: "Kreati vitas dirumuskan dalam istilah person (pribadi), process (proses), press (dorongan), dan product (produk). Keempat jenis definisi tentang kreativitas ini disebut sebagai “Four P'S of Creativity" yang saling berkaitan yaitu pribadi yang kreatif akan melibatkan diri dalam proses kreatif, dan dengan dukungan dan dorongan (press) dari lingkungan akan menghasilkan produk kreatif".

Dua kelompok pengujian yaitu kelompok yang melakukan kegiatan outdoor education berlandaskan experiential learning dan yang tidak melakukan setelah diujikan dengan pengujian, maka diperoleh suatu hasil yaitu kelompok yang melakukan kegiatan outdoor education berlandaskan experiential learning memiliki kreativitas yang lebih tinggi dibandingkan dengan yang tidak mengikuti kegiatan tersebut. Hal ini menunjukkan bahwa setelah proses kegiatan outdoor education berlandaskan experiential learning, tampak bahwa kegiatan yang diberikan memiliki dampak yang positif terhadap kreativitas, dibandingkan dengan siswa yang tidak melakukan kegiatan tersebut.

Dari pembahasan penelitian tentang perbedaan pengaruh outdoor education berlandaskan experiential learning terhadap kreativitas di atas, dapat dipahami bahwa kegiatan outdoor education tersebut 
54 | Asep Ramdan Afriyuandi

Pengaruh Outdoor Education Berlandaskan Experiential Learning Terhadap Kreativitas

secara teoretis dapat meningkatkan kreativitas, hal itu didukung pula dengan pengujian kuantitatif terhadap data pre-test dan pos-test variabel kreativitas. Disamping itu, kegiatan outdoor education di alam terbuka memberikan pengalaman bagi siswa, keadaan alam yang indah, lapangan rumput yang luas, udara yang segar, aliran air yang jernih dan pohon yang rindang menimbulkan rasa gembira dan senang dalam melakukan pembelajaran, seperti yang dikemukakan oleh Kardjono (2009: hlm.96) bahwa: "pengertian outdoor education terbagi dalam dua penekanan yang berbeda, yaitu pada tekan psiko-sosial dan pada tugas alam dan lingkungan. Dari definisi di atas dapat disimak, Outdoor education adalah sebuah pendidikan yang menggunakan pengalaman belajar di luar ruangan dengan tujuan untuk pengembangan seseorang secara menyeluruh dari hasil pengamatan dan tanggapan melalui perasaan, pendengaran, pengelihatan, cobaan, sentuhan, dan penciuman.

Hasil penelitian menunjukkan bahwa program tersebut akan membawa dampak positif terhadap aspek kreativitas pada aspek fluiditas (kelancaran), aspek fleksibilitas (keluwesan), aspek orisinalitas (keaslian), aspek elaborasi (kerincian), aspek evaluasi (penilaian), aspek rasa ingin tahu, aspek imajinatif, aspek tertantang oleh kemajemukan, aspek berani mengambil resiko dan aspek menghargai. Adapun efek peningkatan berkisar antara 0,34 - 0,67 dan dari data penelitian ini sangat mendukung penelitian yang telah penulis lakukan sehingga pendapat atau penelitian tersebut dapat dijadikan pemerkuat dasar dari hasil penelitian yang peneliti lakukan. Sehingga dari itu semua, dapat penulis simpulkan penelitian ini yaitu bahwa outdoor education berlandaskan experiential learning dapat mempengaruhi kreativitas dan semua aspek kreativitas tersebut, yaitu aspek fluiditas (kelancaran), aspek fleksibilitas (keluwesan), aspek orisinalitas (keaslian), aspek elaborasi (kerincian), aspek evaluasi (penilaian), aspek rasa ingin tahu, aspek imajinatif, aspek tertantang oleh kemajemukan, aspek berani mengambil resiko dan aspek menghargai.

\section{KESIMPULAN}

Penelitian ini menghasilkan kesimpulam yakni
1. Kegiatan Outdoor education berlandaskan experiential learning dapat meningkatkan kreativitas

2. Terdapat ciri kreativitas pada siswa dilihat dari ciri kognitif (aptitude) dan ciri afektif (non-aptitude) sebelum dan sesudah penerapan Outdoor Education yang berlandaskan Experiential Learning

\section{DAFTAR PUSTAKA}

Juliante, Tite. (2010). Model Pembelajaran Inkuiri Dalam Pendidikan Jasmani Untuk Mengembangkan Kreativitas Siswa Sekolah Dasar. Disertasi Doktor pada Pendor SPs UPI.Bandung : tidak diterbitkan 
55 | Asep Ramdan Afriyuandi

Pengaruh Outdoor Education Berlandaskan Experiential Learning Terhadap Kreativitas

Kardjono.(2009). Pengendalian Diri (Self Control) Melalui Outdoor Education. Disertasi Doktor pada Pendor SPs UPI.Bandung : tidak diterbitkan.

Lutan, Rusli. (2008). Pedagogy pendidikan Jasmani: Review kuliah. Bandung: Sekolah Pasca Sarjan UPI. Tidak diterbitkan.

Milest, Jhon. C and Priest, Simon. (1990). Adventure Education. Publisher: Ventury Pub. (State College, PA).

Munandar, U (1988). Kreativitas

Sepanjang Masa. Jakarta:

Grasindo. (1999). Kreativitas Dan Keberbakatan (Strategi
Mewujudkan Strategi Dan Bakat).

Jakarta: Gramedia.

(2009). Pengembangan

Kreativitas Anak Berbakat.

Jakarta: Rineka Cipta.

Supriadi, D. (1994). Kreativitas, Kebudayaan, dan Perkembangan Iptek. Bandung: Alfabeta.

Taniguchi, Stacy T. (2004). Outdoor Education And Meaningful Learning: Finding The Attributes Of Meaningful Learning Experiences In An Outdoor Education Program. (Journal) 